\title{
Multiplication of soilborne wheat mosaic virus (SBWMV) in wheat roots infected by a soil carrying SBWMV and wheat yellow mosaic virus (WYMV)
}

Djabbar HARIRI, Michel COURTILLOT, Pascal ZAOUI, Hervé LAPIERRE

I.N.R.A., Station de Pathologie végétale, Route de Saint-Cyr, F 78000 Versailles

Soft winter wheat cultivars were infected in the field or in a growth chamber with an inoculum consisting of soilborne wheat mosaic virus (SBWMV) and wheat yellow mosaic virus (WYMV). Only SBWMV was screened by ELISA in the leaves and roots of plants. Among 33 wheat cultivars studied in the field, 9 (Capitole, Cargo, Fortuna, Moulin, Rescler, Albatros, Fidel, Rempart, Tarasque) were resistant to the SBWMV-WYMV complex. However, the first five cultivars mentioned above showed transitory mosaic symptoms. Cultivar Pernel, which is susceptible to WYMV and resistant to SBWMV in the field did not show a breakdown of resistance to SBWMV. This might be accounted for by the spread of SBWMV in the plant shoots. In the cultivars resistant to SBWMV, virus could not be detected in the leaves, but was clearly identified in the roots. The virus could be detected only during a part of the life cycle of the plant. Upon completion of the tillering stage, virus concentrations were equally high in the resistant and in the susceptible cultivars. SBWMV associated with all the resistant cultivars studied could be carried to healthy plants by zoospores of Polymyxa graminis at tacking the roots at least during the tillering stage. However, the level of inoculum present in the plants of each cultivar was not evaluated. At the end of the life cycle of wheat, resting spores of $P$. graminis do occur in all wheat cultivars resistant to the SBWMV-WYMV complex. In a growth chamber after inoculation by a soil carrying SBWMV and WYMV, root multiplication of SBWMV has been tested in eleven field-resistant cultivars : Albatros, Apexal, Avalon, Cocagne, Capitole, Fleuron, Fortuna, Moulin, Pernel, Sabre, Tarasque. Sabre and Avalon showed the same virus concentration as Hardi the susceptible cultivar. In contrast, Albatros and Cocagne showed a lower virus concentration in their roots (the concentration was 10 to 200 times lower in Cocagne than in Hardi). The other cultivars showed an intermediate behavior. The genetic origin of this resistance is discussed.

Additional key words : ELISA, Polymyxa graminis, resistance.

\section{RÉSUMÉ}

Multiplication du virus de la mosaique du blé(VMB $=S B W M V)$ dans les racines de blé infectées par un sol portant le VMB et le virus de la mosaïue jaune du blé $(V M J B=W Y M V)$.

Des blés tendres d'hiver ont été soumis au champ ou en enceinte climatique à un inoculum constitué par le complexe virus de la mosaïque du blé (VMB), virus de la mosaïque jaune du blé (VMJB). Seul le VMB a été recherché à l'aide d'un test immunoenzymatique dans les feuilles et les racines des plantes.

Au champ, sur 33 cultivars étudiés, 9 d'entre eux : "Capitole, Cargo, Fortuna, Moulin, Rescler, Albatros, Fidel, Rempart, Tarasque " sont symptomatologiquement résistants au complexe VMB-VMJB. Cependant les 5 premiers blés cités présentent des symptômes fugaces de mosaïque.

Pour le cultivar «Pernel », sensible au VMJB et résistant au VMB au champ, on n'a pas observé de rupture de résistance qui se serait exprimée par une multiplication du VMB dans la partie aérienne des plantes. Si pour les cultivars résistants au champ au VMB on ne peut mettre en évidence une multiplication foliaire, le virus est nettement caractérisé dans les racines. Cette détection n'est possible sur une grande partie des plantes que pendant une période assez brève de la vie de la céréale. Au stade plein tallage, les concentrations virales sont aussi élevées dans les cultivars résistants que dans les cultivars sensibles.

Au moins au stade du tallage, le VMB est présent dans tous les cultivars résistants et peut être transmis à des plantes saines par les zoospores de Polymyxa graminis hébergées par leurs racines. Les quantités d'inoculum présentes dans les plantes de chaque cultivar n'ont pas été évaluées.

En fin de cycle végétatif du blé, on peut trouver les formes de conservation de $P$. graminis chez tous les cultivars de blé résistants au complexe VMB-VMJB.

On a recherché le VMB dans les racines des plantes de 11 cultıvars (Albatros, Apexal, Avalon, Cocagne, Capitole, Fleuron, Fortuna, Moulin, Pernel, Sabre, Tarasque) inoculés en enceinte climatique par l'intermédiaire d'un sol contenant le VMB et le VMJB. On observe de grandes différences de niveau de la multiplication du VMB dans les racines de ces différents cultivars. Sabre et Avalon multiplient aussi bien le virus que le cultivar sensible Hardi. Au contraire Albatros et surtout Cocagne multiplient très peu de VMB dans leurs racines ; suivant les essais, la concentration en VMB est de 10 à 200 fois pius faible chez Cocagne que chez Hardi. Les autres cultivars ont des comportements intermédiaires. Les bases génétiques de ces résistances sont discutées. 


\section{INTRODUCTION}

Soilborne wheat mosaic virus (SBWMV), which is transmitted by Polymyxa graminis Led. and belongs to the proposed Furovirus group (SHIRAKO \& BRAKKE, 1984), is spreading across Europe (LAPIERRE et al., 1985). Presently, the sites most severely infested with SBWMV in France are restricted to the central part of the country. However, additional sites were detected in 1985 , which suggests that the virus in spreading into southern France.

Field resistance to SBWMV is commonly encountered in soft winter wheat, but neither the mechanisms of this resistance nor the genes controlling the resistance have been clearly identified. Depending on workers and plant material used, a single gene (DUBEY et al., 1970, MODAWI et al., 1982) or several genes (NAKAGAWA et al., 1959, SHAALAN et al., 1966, MERKLE \& SMITH, 1983) are assumed to be involved in this resistance.

In central France, SBWMV is frequently associated with wheat yellow mosaic virus (WYMV), a virus closely related to wheat spindle streak mosaic virus (WSSMV) (USUGI \& SAITO, 1979). Both viruses are transmitted by $P$. graminis, and possible breakdown of resistance to SBWMV in the presence of WSSMV has been reported for the cultivar Newton (LOMMEL \& WILLIS, 1984, LOMMEL et al., 1986).

In a previous study of twelve soft winter wheat cultivars showing field resistance to SBWMV, we reported (LAPIERRE et al., 1985) a low virus concentration or absence of virus in shoots and a low virus concentration in roots of naturally infected plants. The purpose of this study was to compare multiplication of SBWMV in the roots of cultivars resistant or susceptible to this virus when infected in the field or in a growth chamber through soil carrying SBWMV and WYMV.

\section{MATERIALS AND METHODS}

\section{A. Field experiments}

Plants and inoculum were taken from an experimental plot at Onzain, Loir-et-Cher. In this plot which was heavily infested with both SBWMV and WYMV, a wheat cultivar susceptible to both viruses was sown in 1983. For the present investigation, thirty three cultivars of wheat and three of barley were sown during October 1984. Two randomized replicates were planted. Phenological stages were characterized using Feeke's scale. In order to characterize the reaction of 33 wheat cultivars to SBWMV and WYMV, different categories were used, based on the presence or absence of mosaic symptoms, on the time of symptom appearance, and on the percentage of infected plants.

\section{B. Inoculation of SBWMV in growth chamber}

Soil (inoculum source) collected in March, 1984 was sieved $(1 \times 1 \mathrm{~cm}$ mesh), placed in $5 \mathrm{~kg}$ containers and stored at $4{ }^{\circ} \mathrm{C}$. This inoculum remained highly infective for 4-6 months.
Wheat seeds were germinated in Petri dishes for 2 days on moistened filter paper. Germinating seeds were transplanted into flats $(30 \times 50 \times 6 \mathrm{~cm})$ containing a mixture of soil and sterile sand (W/W), and were arranged in separate rows. The susceptible cultivar (Hardi) was included in each experiment. Flats were kept on trays at $15{ }^{\circ} \mathrm{C}$ in a growth chamber with $16,000 \mathrm{~lx}$ light intensity and a $16 \mathrm{~h}$ photoperiod.

Flats were watered frequently during the first 5 days after transplanting. In the tests designed for biological detection of viruliferous $P$. graminis, the seedlings of Hardi to be inoculated were held in separate containers. Under these experimental conditions, mosaic symptoms were observed on only a few plants one to 2 months after exposure to the soil or root inocula.

\section{Detection of SBWMV and WYMV and compari- son of SBWMV concentration in different plant extracts}

Implementation of the ELISA procedure (CLARK \& ADAMS, 1977) for detecting SBWMV has been described previously (LAPIERRE et al., 1985). Plants from the experimental plots were harvested with their roots intact down to $25 \mathrm{~cm}$ below ground level. Roots were washed, rinsed carefully and plants stored at $4{ }^{\circ} \mathrm{C}$. Roots and leaves were ground for $20 \mathrm{~s}$ in a roller press in the presence of 10 volumes of the buffer per unit weight of plant material. Fractions to be tested were diluted with extracts of healthy plants. A range of infected plant dilutions allowed the measure of the relative virus concentrations for the various extracts to be determined. Optical densities (O.D.) were recorded either after 1-h or 8-h hydrolysis of the substrate. For detection of SBWMV and WYMV under the electron microscope, leaf fragments were dilacerated in the presence of $2 \%$ phosphotungstic acid, $\mathrm{pH} 7$. The extracts obtained were placed on carbon-coated grids. Observations were made with a Philips 300 transmission electron microscope at $80 \mathrm{kV}$.

\section{Detection of the cystosori of Polymyxa sp.}

The presence of cystosori of Polymyxa sp. in fieldinfected wheat or barley roots was tested as follows : for each cultivar, root samples from 5 to 10 plants were obtained. From this sample 40 to 70 fragments of $8 \mathrm{~mm}$ average length (including branches) and $200 \mu \mathrm{m}$ average diameter were taken. These fragments with a total length of 30 to $60 \mathrm{~cm}$ were examined under the light microscope after staining with methyl blue.

\section{RESULTS}

\section{A. Development of mosaic symptoms in wheat culti- vars grown in a field infested with SBWMV and WYMV}

Initial mosaic symptoms were observed in the field in late January (stage 2) (table 1). Most plants of the highly susceptible cultivars expressed mosaic symptoms on February 20 (stage 3), whereas plants of 
TABLE 1

Development of mosaic symptoms on winter wheat cultivars grown in a soil carrying SBWMV and WYMV (percentage estimated from about 1,000 plants).

Evolution des symptômes de mosaïque chez différents cultivars de blé d'hiver cultivés dans un sol contenant le VMB et le VMJB (estimation du pourcentage de plantes malades à partir d'environ 1000 pieds).

\begin{tabular}{|c|c|c|c|c|c|}
\hline \multirow{2}{*}{ Lines or cultivars of soft wheat } & \multicolumn{4}{|c|}{ Percentage of plants with mosaic symptoms } & \multirow{2}{*}{$\begin{array}{l}\text { Susceptibility of wheat } \\
\text { cultivars to the } \\
\text { SBWMV-WYMV complex }\end{array}$} \\
\hline & Janv. 28 & Febr. 20 & April 17 & June 10 & \\
\hline PERNEL & 20 & $>50$ & $>50$ & $>50$ & \\
\hline BEAUCHAMP & 15 & $>50$ & $>50$ & $>50$ & \multirow{13}{*}{ high } \\
\hline CHOPIN & 30 & $>50$ & $>50$ & $>50$ & \\
\hline BERLIOZ & 0 & $>50$ & $>50$ & $>50$ & \\
\hline CATON & 0 & $>50$ & $>50$ & $>50$ & \\
\hline CAMP-REMY & 0 & $>50$ & $>50$ & $>50$ & \\
\hline GALAHAD & 0 & $>50$ & $>50$ & $>50$ & \\
\hline HARDI & 0 & $>50$ & $>50$ & $>50$ & \\
\hline PLUTON & 0 & $>50$ & $>50$ & $>50$ & \\
\hline SENSOR & 0 & $>50$ & $>50$ & $>50$ & \\
\hline TENOR & 0 & $>50$ & $>50$ & $>50$ & \\
\hline 777 & 0 & $>50$ & $>50$ & $>50$ & \\
\hline 6.69 & 0 & $>50$ & $>50$ & $>50$ & \\
\hline FCS 80 & 0 & $>50$ & $>50$ & $>50$ & \\
\hline CARAT & 0 & 20 & $>50$ & $>50$ & \multirow{8}{*}{ moderate } \\
\hline CHAMPLEIN & 0 & 15 & $>50$ & $>50$ & \\
\hline EPIROUX & 10 & 40 & $>50$ & $>50$ & \\
\hline PRIAM & 0 & 30 & $>50$ & $>50$ & \\
\hline RIOL & 0 & 10 & $>50$ & $>50$ & \\
\hline IC 8114 & 20 & 40 & $>50$ & $>50$ & \\
\hline GALAXIE & 0 & 30 & $>50$ & $>50$ & \\
\hline FESTIN-FRANDOC & 0 & 5 & $>50$ & $>50$ & \\
\hline COURTEL & 0 & 5 & 30 & 5 & \multirow{2}{*}{ mild } \\
\hline TRACY & 0 & 10 & 30 & 20 & \\
\hline CAPITOLE & 0 & $<5$ & 0 & 0 & \multirow{5}{*}{ very mild } \\
\hline CARGO & 0 & 0 & $<5$ & 0 & \\
\hline FORTUNA & 0 & 0 & $<10$ & 0 & \\
\hline MOULIN & 0 & 0 & $<10$ & 0 & \\
\hline RESCLER & 0 & 0 & $<1$ & 0 & \\
\hline ALBATROS & 0 & 0 & 0 & 0 & \multirow{4}{*}{0} \\
\hline FIDEL & 0 & 0 & 0 & 0 & \\
\hline REMPART & 0 & 0 & 0 & 0 & \\
\hline TARASQUE & 0 & 0 & 0 & 0 & \\
\hline
\end{tabular}

more resistant cultivars showed similar symptoms one month later. For other cultivars, symptoms, if present, were more or less transitory. Since climatic conditions were favourable for the expression of SBWMV and WYMV symptoms, the 4 symptomless cultivars (Albatros, Fidel, Rempart, Tarasque) may be regarded as resistant to this association of viruses. No symptoms were observed on the 3 barley cultivars (Illia, Panda, Plaisant).

Further tests were conducted on a few cultivars with mosaic symptoms (ELISA for SBWMV and leaf dip in electron microscopy for WYMV). Pernel was the only cultivar resistant to SBWMV leaf multiplication and susceptible to WYMV.

\section{B. Concentration of SBWMV in roots of soft winter wheat during the life cycle of the plant}

Nine wheat cultivars field-resistant to SBWMV were compared with susceptible cultivars and the 3 barley cultivars. Six samples were collected between late
January (stage 2) and late June (stage 10.5.3). The percentages of infected plants for the different cultivars are listed in table 2. SBWMV was detected in roots of the susceptible cultivar Hardi up to the $1 / 1000$ dilution of crude extracts (fig. 1) in the first 3 samples.

In the first samples, the percentage of infected plants was very high in cv. Hardi $(90 \%)$ and much lower $(0-30 \%)$ in the other cultivars. This difference can be expressed as the quantity of O.D. units for 10 plants separately analyzed (table 3 ). From this first estimation the cultivar classification agrees partially with the levels of leaf susceptibility already known. For cultivars Chopin, Carat and Beauchamp, O.D. measurement by ELISA procedure provided an estimate value inferior to susceptibility rating. For cultivars Moulin and Fidel which are resistant in the field, the O.D. measured was more than three times that of the healthy control ; these cultivars can be rated similar as to the hybrids Courtel and Festin-Frandoc.

Samples II did not reveal any great increase in the percentage of plants exhibiting mosaic symptoms ; but a considerable increase of this percentage was observed 
TABLE 2

Percentage of $S B W M V$ infected roots in different cullivars of wheat and barley grown in a field carrying $S B W M V$ and $W Y M V$. ELISA detection of SBWMV.

(-) No analysis, * barley cultivars, nb: number of plants tested.

Evolution, pour différents cultivars de blé, du pourcentage de plantes pour lesquelles on détecte le VMB dans les racines après une infection au champ dans un sol contenant le VMB et le VMJB. (-) Non analysés, * cultivar d'orge, $n b:$ nombre de plantes éprouvées.

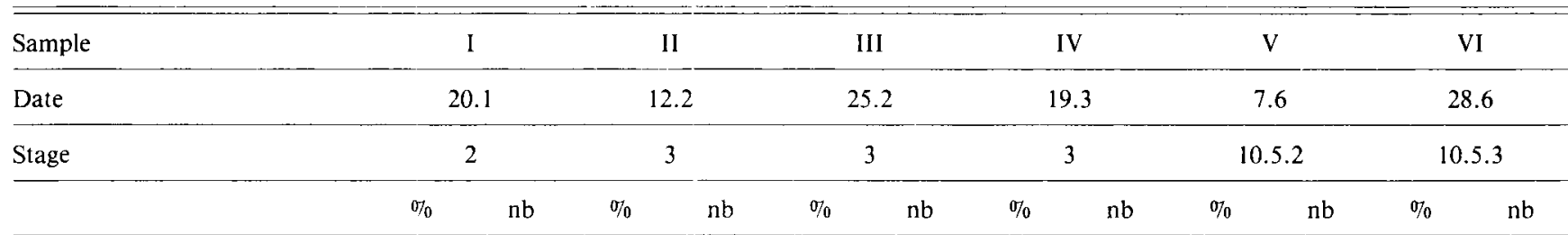

\section{Cultivars}

\begin{tabular}{|c|c|c|c|c|c|c|c|c|c|c|c|c|}
\hline ALBATROS & 10 & $(10)$ & 0 & $(20)$ & 50 & $(18)$ & 0 & $(10)$ & 0 & $(10)$ & 0 & $(10)$ \\
\hline CARGO & 0 & $(10)$ & 10 & $(20)$ & 30 & $(20)$ & 10 & $(10)$ & 0 & $(10)$ & 0 & $(10)$ \\
\hline CAPITOLE & 0 & (10) & 10 & $(20)$ & 70 & (14) & 20 & $(10)$ & 0 & $(10)$ & 0 & $(10)$ \\
\hline FORTUNA & 0 & $(10)$ & 0 & $(20)$ & 50 & (18) & 10 & $(10)$ & 0 & (10) & 0 & $(10)$ \\
\hline PERNEL & 0 & $(10)$ & 30 & (10) & 60 & $(10)$ & 10 & $(10)$ & 10 & $(10)$ & 10 & $(10)$ \\
\hline REMPART & 0 & $(10)$ & 20 & $(20)$ & 70 & $(10)$ & 40 & $(10)$ & 20 & (10) & 0 & $(10)$ \\
\hline MOULIN & 20 & $(10)$ & 20 & $(20)$ & 100 & (18) & 20 & $(10)$ & 0 & $(10)$ & 0 & $(10)$ \\
\hline TARASQUE & 10 & $(10)$ & 10 & (20) & 20 & (10) & $(-)$ & & 10 & (10) & 10 & $(10)$ \\
\hline RESCLER & 0 & $(10)$ & 5 & $(20)$ & 40 & $(10)$ & $21)$ & (10) & 0 & (10) & 0 & $(10)$ \\
\hline FIDEL & 30 & $(10)$ & 40 & $(20)$ & 20 & (15) & $(-)$ & & 0 & (10) & 0 & $(10)$ \\
\hline HARDI & 90 & $(10)$ & 100 & $(10)$ & 100 & $(8)$ & 100 & $(10)$ & 70 & $(10)$ & 40 & $(10)$ \\
\hline PANDA * & 0 & $(10)$ & 0 & $(10)$ & 0 & ( 8 ) & $(-)$ & & $(-)$ & & $(-)$ & \\
\hline PLAISANT * & 0 & $(10)$ & 0 & $(10)$ & 0 & $(8)$ & $(-)$ & & $(-)$ & & $(-)$ & \\
\hline ILLIA * & 0 & $(10)$ & 0 & $(10)$ & 0 & $(8)$ & $(-)$ & & $(-)$ & & $(-)$ & \\
\hline
\end{tabular}

TABLE 3

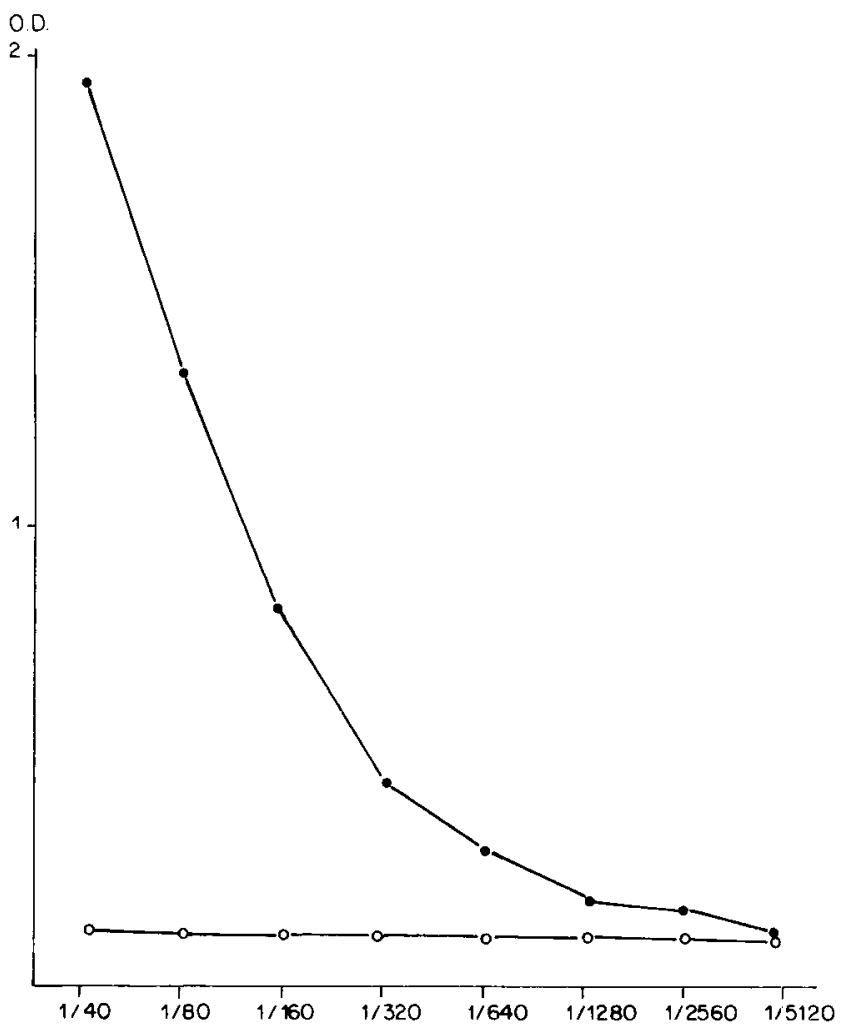

Dilution of root extracts Dilution des extraits racinaires

Figure 1

ELISA detection of SBWMV in field-contaminated roots of $\mathrm{cv}$. Hardi.

$\begin{array}{ll}\text { Infected roots } & \text { Racines infectées } \\ \text { Healthy roots } & \text { Racines saines }\end{array}$

Détection en ELISA du VMB dans des racines de plantes du $c v$. Hardi contaminé au champ.
SBWMV in the roots of wheat cultivars at the early tillering stage (sample l). O.D. in ELISA measured after $60 \mathrm{mn}$ of substrate hydrolysis.

$V M B$ dans les racines de différents cultivars de blé au stade début tallage (prélèvement I).

\begin{tabular}{|c|c|}
\hline CULTIVARS & Sum of O.D. (10 plants) \\
\hline PERNEL & 1.115 \\
\hline RESCLER & 1.151 \\
\hline REMPART & 1.151 \\
\hline CARGO & 1.400 \\
\hline CAPITOLE & 1.803 \\
\hline FORTUNA & 1.661 \\
\hline ALBATROS & 2.130 \\
\hline TARASQUE & 2.359 \\
\hline MOULIN & 3.647 \\
\hline FIDEL & 3.807 \\
\hline COURTEL & 3.885 \\
\hline FESTIN-FRANDOC & 3.784 \\
\hline TRACY & 3.997 \\
\hline CHOPIN & 6.622 \\
\hline CARAT & 6.636 \\
\hline BEAUCHAMP & 7.486 \\
\hline GALAXIE & 8.695 \\
\hline CAMP-REMY & 10.661 \\
\hline BERLIOZ & 11.122 \\
\hline 777 & $>12$ \\
\hline PLUTON & $>14$ \\
\hline IC 8114 & $>15$ \\
\hline CATON & $>20$ \\
\hline SENSOR & $>20$ \\
\hline HARDI & $>20$ \\
\hline CHAMPLEIN & $>20$ \\
\hline EPIROUX & $>20$ \\
\hline RIOL & $>20$ \\
\hline TENOR & $>20$ \\
\hline GALAHAD & $>20$ \\
\hline PRIAM & $>20$ \\
\hline 6.69 & $>20$ \\
\hline FCS 201 & $\geq 20$ \\
\hline HARDI (non-infected) & 1.009 \\
\hline
\end{tabular}


TABLE 4

ELISA detection of SBWMV in the roots of few wheat cultivars (sample III). O.D. measured after $60 \mathrm{mn}$ substrate hydrolysis.

Détection en ELISA du VMB dans les racines de quelques cultivars de blé (prélèvement III).

\begin{tabular}{|c|c|c|c|c|c|}
\hline \multirow{2}{*}{ Sample $n^{\circ}$} & \multicolumn{4}{|c|}{ Cultivars tested } & \multirow{2}{*}{ Control } \\
\hline & MOULIN & PERNEL & RESCLER & HARDI & \\
\hline 1 & 1.623 & 0.237 & 0.760 & 1.270 & 0.204 \\
\hline 2 & 1.239 & 1.230 & 0.708 & 0.831 & 0.249 \\
\hline 3 & 1.374 & 1.215 & 0.211 & 1.264 & 0.240 \\
\hline 4 & 1.489 & 1.269 & 0.237 & 1.266 & 0.210 \\
\hline 5 & 1.654 & 1.502 & 1.055 & 0.832 & - \\
\hline 6 & 1.058 & 1.689 & 0.212 & 0.837 & - \\
\hline 7 & 1.059 & 0.236 & 0.211 & 1.323 & - \\
\hline 8 & 1.406 & 0.190 & 0.259 & 1.045 & - \\
\hline
\end{tabular}

13 days later. At this time the virus concentration of field-resistant cultivars was close to that of the susceptible ones (table 4).

The percentage of plants in which SBWMV was detected decreased gradually from sample IV (stage 3, March 19). At the same time, the O.D. Values measured in the resistant cultivars dropped to a much lower level than those of the susceptible control (table 5). Sample V (stage 10.5.1) showed that SBWMV could still be detected in a rather large percentage of plants from susceptible cultivars, whereas it was detected in an average of 2 out of 100 among resistant ones (table 2).

The roots of 3 barley cultivars grown under similar conditions, showed no SBWMV-specific reaction in the ELISA test for the first 3 samples.

\section{Ability of SBWMV-resistant wheat roots to host viruliferous $P$. graminis in the field}

Seedlings of cv. Hardi were infected with SBWMV in a growth chamber using soil containing variable amounts of plant roots from infested plots. Unlike the barley cultivars Illia and Plaisant, all wheat cultivars tested carried viruliferous $P$. graminis (table 6).
TABLE 6

Transmission of SBWMV to cv. 'Hardi' seedlings by root fragments of wheat and barley plants grown in SBWMV - WYMV contaminated field.

Essai de transmission du VMB à de jeunes plantes du cv. « Hardi » par l'intermédiaire de racines de différents cultivars de blé et d'orge (l) provenant d'une parcelle contenant le VMB et le $V M J B\left(^{*}\right)$ sensible.

\begin{tabular}{lcc}
\hline & \multicolumn{2}{c}{ Number of seedlings (cv. Hardi) } \\
\cline { 2 - 3 } as inocultum source & Infected & Total tested \\
\hline TARASQUE & 1 & 6 \\
FIDEL & 1 & 21 \\
RESCLER & 2 & 4 \\
CARGO & 6 & 13 \\
ALBATROS & 5 & 11 \\
FORTUNA & 8 & 13 \\
PERNEL & 5 & 6 \\
MOULIN & 6 & 6 \\
CAPITOLE & 12 & 14 \\
REMPART & 13 & 15 \\
\hline COURTEL $(*)$ & 5 & 11 \\
HARDI $(*)$ & 1 & 6 \\
\hline PLAISANT $\left({ }^{(}\right)$ & 0 & 8 \\
ILLIA $\left({ }^{1}\right)$ & 0 & 13 \\
\hline \hline
\end{tabular}

Because of poor test replicability (no correlation between amount of root inoculum and number of infected plants), no difference could be distinguished among cultivars.

\section{Field presence of cystosori of $P$. graminis in roots of various resistant soft wheat cultivars}

Analyses were made in June (stage 10.5.2) and July (stage 11.1) (table 7). The number of cystosori observed varied considerably between the 2 samplings. For example in June, no cystosori were observed in Galahad plants showing foliar symptoms of SBWMV. All resistant cultivars tested carried $P$. graminis cystosori. However, the method described does not permit a comparison between the different cultivars.

TABLE 5

Root detection of SBWMV in wheat. Groups of plant roots in relation to O.D. in ELISA for 3 consecutive field samplings of cultivars resistant or susceptible to $S B W M V$. (c) : Control.

Détection du VMB dans les racines de différents cultivars de blés pour 3 prélèvements successifs. Groupes de plantes en fonction des D.O. en ELISA. (c) : Témoin.

\begin{tabular}{|c|c|c|c|c|c|c|c|c|c|c|c|c|c|c|c|c|c|c|}
\hline \multirow{2}{*}{$\frac{\text { CULTIVARS }}{\text { Sample Echantillons }}$} & \multicolumn{3}{|c|}{ REMPART } & \multicolumn{3}{|c|}{ MOULIN } & \multicolumn{3}{|c|}{ PERNEL } & \multicolumn{3}{|c|}{ RESCLER } & \multicolumn{3}{|c|}{ CAPITOLE } & \multicolumn{3}{|c|}{ HARDI } \\
\hline & II & III & IV & 11 & III & IV & II & III & IV & II & III & IV & II & III & IV & II & III & IV \\
\hline \multicolumn{19}{|l|}{ O.D. groups } \\
\hline O.D. $<1.5 \times \mathrm{C}$ & 13 & 2 & 6 & 13 & 0 & 7 & 3 & 3 & 9 & 16 & 5 & 8 & 18 & 1 & 8 & 0 & 0 & 0 \\
\hline $1.5 \times \mathrm{C} \leqslant$ O.D. $<2.5 \times \mathrm{C}$ & 3 & 1 & 0 & 3 & 0 & 1 & 4 & 0 & 0 & 3 & 0 & 0 & 0 & 3 & 0 & 0 & 0 & 0 \\
\hline $2 \times C \leqslant$ O.D. $<4 \times C$ & 4 & 1 & 4 & 4 & 0 & 2 & 3 & 0 & 1 & 1 & 2 & 2 & 2 & 4 & 2 & 2 & 0 & 0 \\
\hline O.D. $\geqslant 4 \times C$ & 0 & 7 & 0 & 0 & 8 & 0 & 0 & 5 & 0 & 0 & 1 & 0 & 0 & 5 & 0 & 8 & 8 & 10 \\
\hline $\begin{array}{l}\text { Total number of plants tested } \\
\text { Nombre total de plantes éprouvées }\end{array}$ & 20 & 11 & 10 & 20 & 8 & 10 & 10 & 8 & 10 & 20 & 8 & 10 & 20 & 13 & 10 & 10 & 8 & 10 \\
\hline
\end{tabular}


TABLE 7

Estimation of proportion of Polymyxa graminis cystosori on roots of several wheat and one barley cultivar grown on a plot contaminated with both SBWMV and WYMV. (*) Slightly susceptible, $\left(^{* *}\right)$ susceptible, $\left(^{* * *}\right)$ hightly susceptible. $\left({ }^{l}\right)=$ Barley.

$0=$ undetected non détecté

$l=$ rare elements in a single fragment rares éléments dans un seul fragment

$2=$ rare elements in several fragments or rather abundant elements in a single fragment

rares éléments dans plusieurs fragments ou éléments assez fréquents dans un fragment

$3=$ abundant elements in 2 or 3 fragments éléments abondants dans 2 ou 3 fragments

4 = abundant elements in 4 to 6 fragments éléments abondants dans 4 à 6 fragments

$5=$ abundant elements in 7 to 9 fragments éléments abondants dans 7 à 9 fragments

$6=$ abundant elements in 10 to 15 fragments éléments abondants dans 10 à 15 fragments

$7=$ abundant elements in more than 15 fragments éléments abondants dans plus de 15 fragments

- not analysed non analysé.

Abondance des cystosores de Polymyxa graminis dans les racines de différents cultivars de blé tendre et d'une orge installés sur une parcelle portant le VMB et le VMJB. (*) Peu sensible, (**) sensible, $\left({ }^{* * *}\right)$ très sensible. $(l)=$ Orge.

\begin{tabular}{lcc}
\hline \hline \multirow{2}{*}{ CULTIVARS } & \multicolumn{2}{c}{ Date of sample } \\
\cline { 2 - 3 } & June 10,1985 & July 4,1985 \\
\hline ALBATROS $\left(^{*}\right)$ & 3 & 3 \\
CAPITOLE $\left(^{*}\right)$ & 4 & 7 \\
CARGO $\left(^{*}\right)$ & 3 & 6 \\
FIDEL $\left(^{*}\right)$ & 2 & - \\
FORTUNA (*) & 4 & 1 \\
MOULIN $\left(^{*}\right)$ & 3 & 4 \\
REMPART $\left(^{*}\right)$ & 4 & 6 \\
RESCLER $\left(^{*}\right)$ & 2 & 2 \\
TARASQUE $\left(^{*}\right)$ & 2 & - \\
\hline TRACY $\left(^{* *}\right)$ & 4 & 4 \\
COURTEL $\left(^{* *}\right)$ & 3 & - \\
\hline GALAHAD $\left(^{* *}\right)$ & 0 & 1 \\
\hline ILLIA $\left({ }^{*}\right)$ & & \\
\hline \hline
\end{tabular}

\section{E. Multiplication of SBWMV in soft wheat roots grown in a controlled environment chamber}

\section{Infection rate}

Of the 11 field-resistant cultivars used in this analysis, 5 had already been characterized previously (LAPIERRE et al., 1985). Two other wheat cultivars served as controls : Tracy, slightly susceptible and Hardi, highly susceptible.

SBWMV was generally detected 5 days after seedling exposure to the inoculum. After 10 days, all roots of Sabre and Fleuron carried the virus (table 8). Complete infection was only observed after 20 or 30 days in the other 9 cultivars which are field-resistant or susceptible. The primary inoculum might have been insufticient or some cultivars express some resistance to inoculation. All field-resistant cultivars can actually be infected.

\section{TABLE 8}

Kinetics of SBWMV infection in the roots of various soft wheat cultivars (rate of infected plants calculated on 12 plant samples). (Growth chamber conditions, soil inoculum, ELISA detection). * Susceptible cultivar.

Cinétique de l'infection par le VMB de racines de différents cultivar de blé tendre. Le taux d'infection est calculé à partir de l'analyse de 12 plantes (contamination en chambre climatique par un sol contenant le VMB et le VMJB). *: Cultivar sensible.

\begin{tabular}{lccc}
\hline & \multicolumn{3}{c}{ Number of days after infection } \\
\cline { 2 - 4 } CULTIVARS & 10 & 20 & 30 \\
\hline SABRE & 100 & 100 & 100 \\
FLEURON & 100 & 100 & 100 \\
\hline TARASQUE & 91 & 100 & 100 \\
TRACY $\left(^{*}\right)$ & 91 & 100 & 100 \\
AVALON & 83 & 100 & 100 \\
APEXAL & 75 & 100 & 100 \\
PERNEL & 75 & 100 & 100 \\
CAPITOLE & 83 & 83 & 100 \\
HARDI $\left(^{*}\right)$ & 91 & 91 & 100 \\
FORTUNA & 66 & 75 & 100 \\
ALBATROS & 58 & 83 & 100 \\
MOULIN & 58 & 75 & 100 \\
COCAGNE & 58 & 68 & 100 \\
\hline
\end{tabular}

\section{Estimated $S B W M V$ concentration in field-resistant cultivars}

In the same experiment described above an estimation of SBWMV concentration in root extracts was made from 12 plants of 6 different cultivars (fig. 2).

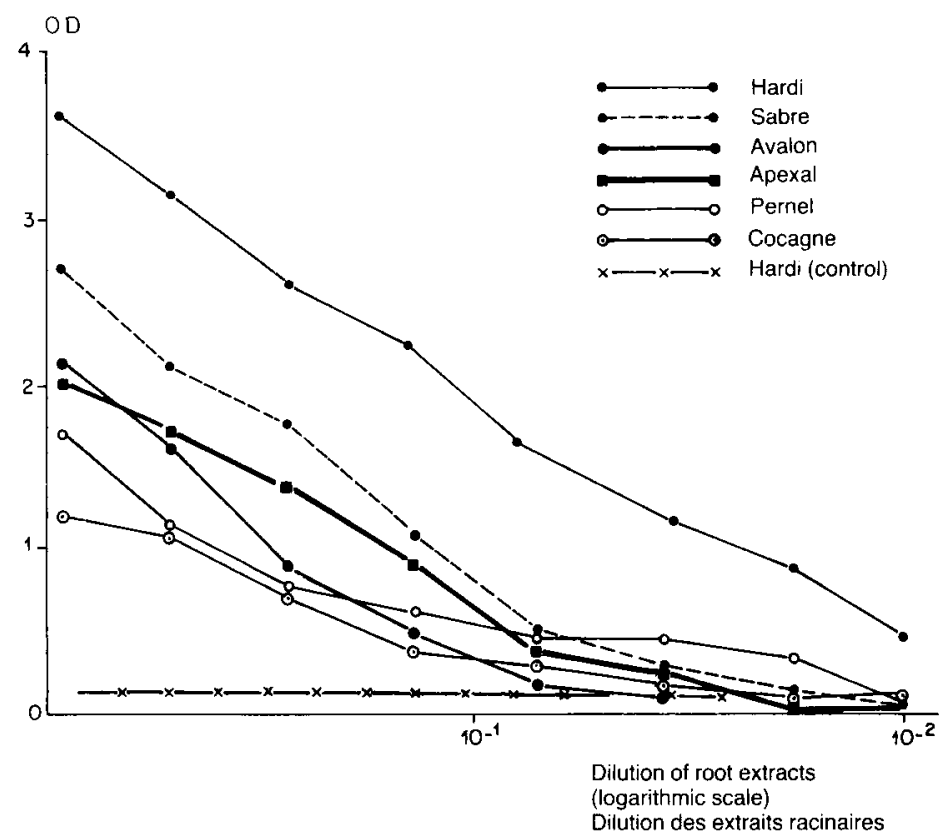

Figure 2

Estimation of SBWMV relative concentration in the roots of soft wheat cultivars (30 days after root infection in a growth chamber, 12 roots samples, O.D. measures in ELISA).

Estimation de la concentration relative du VMB dans les racines de différents cultivars de blé 130 jours d'infection en chambre climatique, échantillon de 12 racines, mesure des D.O. en ELISA). 


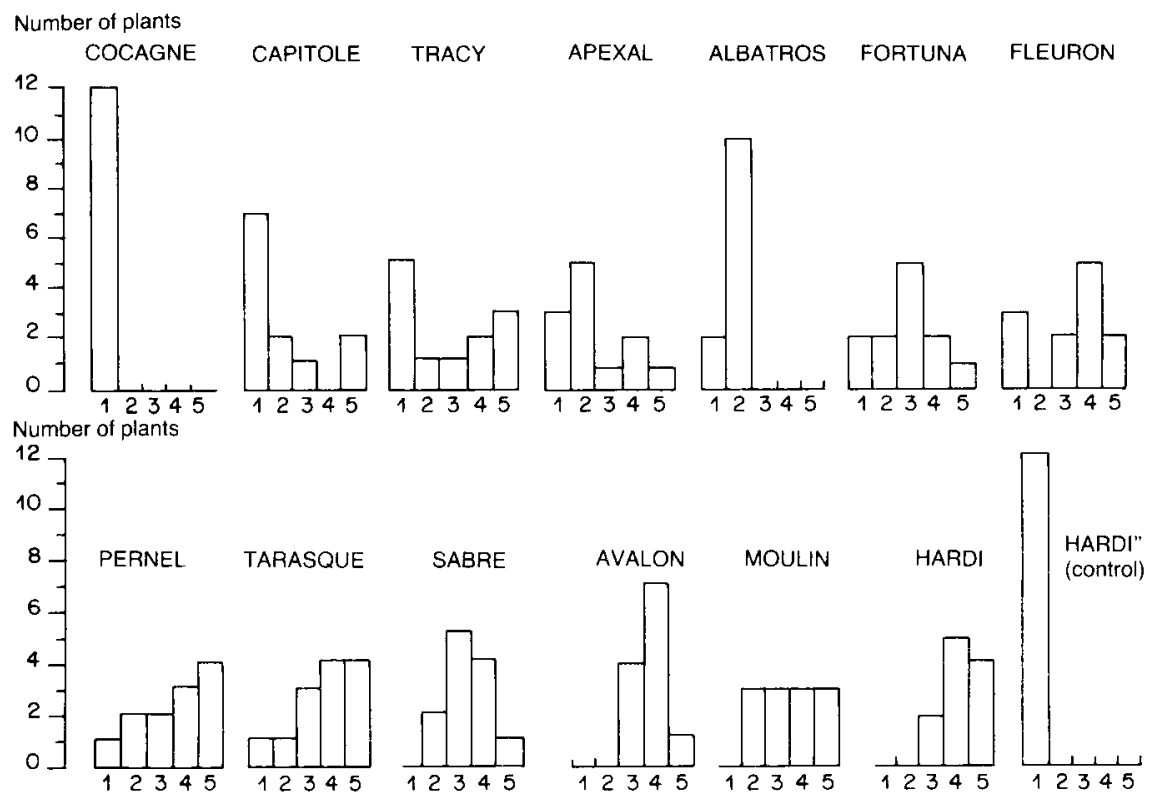

Figure 3

Distribution of SBWMV in the roots of 11 field-resistant and 2 susceptible wheat cultivars. Inoculation in a growth chamber, ELISA measured 30 davs after exposure of seedlings to soil inoculum.

$\begin{array}{llll}\text { l) } O . D .=0 & \text { to }<0.5 & \text { 3) } O . D .=1.0 \text { to }<1.5 & \text { 5) O.D. } \geqslant 2.0\end{array}$

2) $O . D .=0.5$ to $<1.0$ 4) $O . D .=1.5$ to $<2$.

Thirty days after exposure to the inoculum the roots of Cocagne contained about 32 times less virus than those of Hardi. None of the Cocagne plant roots showed high virus concentration (fig. 3). Tracy and the other cultivars showed an intermediate behaviour. A similar result was obtained in 2 other independant experiments.

All our results ( 2 to 4 test depending on cultivars) can be summarized in the form of a temporary classification of resistance of soft wheat cultivars to SBWMV as a function of their ability to multiply the virus in their roots in a growth chamber (table 9).

TABLE 9

Classification of field-resistant wheat cultivars for SBWMV multiplication in the roots of inoculated plants in a growth chamber. (I) Ratio of virus concentration between a tesied cultivar and $c v$. 'Hardi'.

Classement des blés tendres résistants au VMB en fonction de leur capacité à multiplier le virus dans les racines de plantes inoculées en enceinte climatique. (I) Rapport de concentration relative du VMB dans un $\mathrm{cv}$. donné par rapport au cv. " Hardi».

CULTIVARS

Ratio concentration (')

SABRE, AVALON

1,2 à 0,5

TARASQUE

MOULIN

FLEURON

TRACY

APEXAL

PERNEL

FORTUNA

CAPITOLE

\begin{tabular}{ll}
\hline ALBATROS & $\ldots, 2$ à 0,03 \\
\hline COCAGNE & 0,1 à 0,005 \\
\hline
\end{tabular}

Distribution du VMB dans les racines de blé de différents cultivars sensibles ou résistants au champ à ce virus. Contamination en enceinte climatique, mesures en ELISA 30 jours après l'apport de l'inoculum.

\section{CONCLUSIONS}

This study of the field response of 33 wheat cultivars to SBWMV and WYMV in a soil carrying both these viruses showed that 9 cultivars were resistant to this virus association.

In the case of cv. Pernel, susceptibility to WYMV caused no breakdown of SBWMV resistance under field conditions. This result seems opposed to the behaviour of cultivar Newton (LOMMEL et al., 1986), but further observations are needed in more numerous cultivars to characterize eventual possible breakdown of resistance to WYMV in the presence of SBWMV or vice versa.

For 5 cultivars, only transitory mosaic symptoms could be observed, possibly corresponding to temporary leaf multiplication of 1 of the 2 viruses.

There was little or no virus multiplication in leaves of field-resistant cultivars, as shown previously (LAPIERRE et al., 1985). Similar observations were made in WSSMV field-resistant wheat cultivars (HAUFLER \& FULBRIGHT, 1986).

SBWMV was found in the roots of all resistant cultivars in amounts similar to those detected in susceptible cultivars during a short period of cereal growth. At other stages of the life cycle of the plant, the root virus content of field-resistant cultivars was much lower than in susceptible ones or was undetectable in ELISA.

At least close to stage II, the roots of field-resistant cultivars give rise to viruliferous zoospores. Because of the limited or zero spread of SBWMV in the shoots of these cultivars, the virus particles synthesized in the cell roots are likely to be associated with the viruliferous forms of $P$. graminis.

Cystosori are found in the roots of all resistant cultivars by the end of the life cycle of the plant, but no information is available on the field susceptibility of 
seedlings to $P$. graminis nor on the viruliferous capacity of the $P$. graminis resting forms that accumulate in the roots. The reduced percentage of plants with SBWMV-infected roots and the low virus concentration after the critical period might characterize this field resistance of soft winter wheat since such a situation does not occur in susceptible wheat. A possible relationship between this phenomenon and the lack of virus movement to the plant shoots remains to be established.

During present investigations, SBWMV concentration in the roots of resistant cultivars did not develop as described in 1983-1984 in another soil containing only SBWMV (LAPIERRE et al., 1985). Under the latter conditions, root virus concentration remained low in all resistant cultivars. This difference in behaviour remains unexplained.

In the growth chamber, when all 11 field resistant wheat cultivars were tested, SBWMV was detected in their roots. These results and those from field tests show that $P$. graminis can infect all the cultivars studied.

The percentage of infected plants and the root virus concentration varied according to trials. Field-resistant cultivars can, however, tentatively be classified into several categories: Sabre and Avalon are the wheat cultivars that best multiply SBWMV and have a root virus concentration close to that of the susceptible cultivar Hardi.

For 8 field-resistant cultivars, virus root concentration is slightly inferior to that of the susceptible cultivar. In Albatros and especially in Cocagne, SBWMV concentration is at least 10 times less than that of Hardi. A partial resistance to virus inoculation and or virus multiplication might account for the behaviour of Cocagne roots.

In the greenhouse or growth chamber test, other approaches of resistance have been used such as : rating of root symptoms (LARSEN et al., 1985), leaf symptoms (BOCKUS, 1984, HUNGER \& SHERWOOD, 1985 ) and leaf virus concentration (HUNGER \& SHER-
WOOD, 1985), all of which deal with the final stages of the virus-cycle or of the disease. All field-resistant cultivars tested are susceptible to leaf inoculation (McKINNEY, 1948 ; LARSEN et al., 1985).

Three stages of the virus cycle occur before SBWMV could multiply and produce symptoms in leaves: 1) virus inoculation by $P$. graminis, 2 ) virus multiplication in roots, 3) virus movement to plant shoots. For all the resistant soft wheat cultivars tested, it is the third stage of the virus cycle which is affected in the field. This conclusion was one of the hypotheses suggested by LARSEN et al., 1985 as a consequence of root symptoms observed in resistant cultivars after leaf inoculation.

We do not have enough evidence that plant genes could control the 3 stages described above. The gene most commonly encountered in soft wheat is probably responsible for the lack of virus migration in the shoots in field conditions. Cultivar Newton, which was found to have a resistance gene different from that of Homestead (MERKLE \& SMITH, 1983), may be a candidate for the control of resistance to one of the first two stages of the virus cycle.

Cocagne is a good example of a wheat cultivar with resistance characterized by root screening for SBWMV. Among the parents of this cultivar either one, 2 or 3 (Heine VII. ble des Domes, 515) possess genes controlling the resistance to this virus while the fourth (Champlein) is susceptible. The field response of Cocagne roots is yet to be studied and the characters of associated $P$. graminis populations also. If a significantly low number of viruliferous cystosori are synthesized, then growing this type of cultivar would permit a rapid decrease of SBWMV soil inoculum.

\section{Reçu le 19 septembre 1986} Accepté le 3 août 1987.

\section{ACKNOWLEDGEMENTS}

We thank F. BOUCHAIN, regional engineer at the Institut Technique des Céréales et Fourrages, who conducted all the varietal tests in the field. We are also grateful to M. Fouchard, I.N.R.A., Geves, for providing growth chambers.

\section{REFERENCES}

Bockus W. W., 1984. A procedure to identify resistance to wheat soil-borne mosaic in wheat seedlings. Plant Dis., 68, 123-124.

Clark M. F., Adams A. N., 1977. Characteristics of the microplate method of enzyme-linked immunosorbent assay for the detection of plant viruses. J. gen. Virol., 34, 475-483.

Dubey S. N., Brown C. M., Hooker A. L., 1970. Inheritance of field reaction to soilborne wheat mosaic virus. Crop Sci., 10, 93-85.

Hunger R. M., Sherwood J. L., 1985. Use of symptomatology and virus concentration for evaluating resistance to wheat soilborne mosaic virus. Plant Dis., 69, 848-850.

Haufler K. Z., Fulbright D. W., 1986. Identification of winter wheat cultivars and experimental lines resistant to wheat spindle streak mosaic virus. Plant Dis., 70, 31-33.

Lapierre H., Courtillot M., Kusiak C., Hariri Dj., 1985. Résistance au champ des blés en semis d'automne au virus de la mosaique du blé (wheat soilborne mosaic virus). Agronomie, 5, 565-572.

Larsen H. J., Brakke M. K., Langenberg W. G., 1985. Relationships between wheat streak mosaic virus and soilborne wheat mosaic virus infection, disease resistance, and early growth of winter wheat. Plant Dis., 69, 857-862.

Lommel S. A., Willis W. G., 1984. The role of wheat spindle streak and wheat soilborne mosaic viruses in an epiphytotic of resistant wheat in Kansas. Phytopathology, 74, abstract p. 844.
Lommel S. A., Willis W. G., Kendall T. L., 1986. Identification of wheat spindle streak mosaic virus and its role in a new disease of winter wheat in Kansas. Plant Dis., 70, 964-968.

McKinney H. H., 1948. Wheats immune from soil-borne mosaic viruses in the field, susceptible when inoculated manually. Phytopathology, 38, 1003-1013.

Merkle O. G., Smith E. L., 1983. Inheritance of resistance to soilborne mosaic in wheat. Crop Sci., 23, 1075-1076.

Modawi R. S., Heyne E. G., Brunetta P., Willis W. G., 1982. Genetic studies of field reaction to wheat soilborne mosaic virus. Plant Dis., 66, 1183-1184.

Nakagawa M., Soga Y., Watanabe S., Gocho H., Nishio K., 1959. Genetical studies of the wheat mosaic virus. II. Genes affecting the inheritance of susceptibility to strains of yellow mosaic in varietal crosses of wheat. Jpn. J. Breed., 9, 118-120 (Plant Breed. Abstr., 1960, vol. 30, p. 508).

Shaalan M. I., Heyne E. G., Sill J. R., 1966. Breeding wheat for resistance to soilborne wheat mosaic virus, wheat streak virus, leaf rust, stem rust and bunt. Phytopathology, 56, 664-668.

Shirako Y., Brakke M. K., 1984. Two purified RNAs of soilborne wheat mosaic virus are needed for infection. J. gen. virol., 65, 119 127.

Usugi T., Saito Y., 1979. Relationship between wheat yellow mosaic virus and wheat spindle streak mosaic virus. Ann. Phytopathol. Soc. Jpn., 45, 397-400. 